\title{
Financial Autarky and International Business Cycles*
}

\author{
Jonathan Heathcote \\ Stockholm School of Economics \\ Fabrizio Perri \\ Stern School of Business, New York University
}

April 30, 2000

\begin{abstract}
We present a two-country, two-good model in which there do not exist any markets for international trade in financial assets. We compare the predictions of this model to those of two other models, one in which markets are complete and a second in which a single non-contingent bond is traded. We find that only the financial autarky model can generate volatility in the terms of trade similar to that in data for the floating rate period and, at the same time, account for observed cross-country output, consumption, investment and employment correlations. We interpret our findings as evidence that the extent of international borrowing and lending opportunities is important for the international business cycle.
\end{abstract}

Keywords: International business cycles, incomplete markets.

JEL Classification Numbers: E32, F32, F33, F41

\footnotetext{
${ }^{*}$ Corresponding author: Fabrizio Perri, Department of Economics, NYU Stern School of Business, 44 West $4^{\text {th }}$ Street, New York, NY 10012. We are greatly indebted to Andy Atkeson for his help and advice. We also thank Patrick Kehoe, Ranil Salgado, an anonymous referee and workshop participants at the IGIER in Milan, at the SED Meetings in Oxford, at Duke and the Stockholm School of Economics, for helpful comments on an earlier version. Jonathan Heathcote is grateful to the Thouron Award and Fabrizio Perri is grateful to the A. Sloan Foundation for financial assistance.
} 


\section{Introduction}

International real business cycle models with complete markets (see, for example, Backus, Kehoe and Kydland [4]) have trouble accounting for at least three features of international data. Firstly, empirical cross-country consumption correlations are generally similar to cross-country output correlations, whereas existing models typically produce consumption correlations much higher than output correlations. Secondly, investment and employment tend to be positively correlated across countries, whereas the models predict a negative correlation. Thirdly, models generate far less volatility in the terms of trade and the real exchange rate than is seen in the data.

These failures can be understood as follows. The existence of complete markets implies insurance of country-specific risk and the efficient use of resources. Risk sharing induces strong positive cross-country consumption correlations. Efficiency dictates that the optimal response to a productivity shock involves increasing investment and labor supply in the more productive country and reducing them in the less productive country. Thus the cross-country correlations of factor supplies and output in the models are lower than those observed empirically. The equilibrium real exchange rate in complete markets models is closely related to the ratio of consumptions across the two countries. Since consumption is highly correlated across countries in the models, this ratio displays low volatility, and the real exchange rate is consequently less volatile than in the data.

This discussion suggests that introducing frictions in international asset markets might help to resolve some puzzles. Baxter and Crucini [6], Kollman [13] and Arvanitis and Mikkola [1] study economies in which the only asset traded internationally is a non-contingent bond. They find that equilibrium allocations look different from those arising when markets are complete only if productivity shocks are very persistent and do not spill over across national borders.

In this paper we consider an economy in which there do not exist any markets for international asset trade, or, equivalently, in which all international goods trade must be quid pro quo. We call this the financial autarky model, following Cole and Obstfeld [10] who studied this market structure in an exchange economy. We extend Cole and Obstfeld's work by modelling production explicitly in the standard real business cycle tradition.

The central part of the paper consists of a comparison of the usual business cycle statistics for the financial autarky economy with those emerging in economies with a single bond and with complete asset markets. This is done for a range of values for the elasticity of substitution between domestic and foreign traded goods, and for a range of specifications for the productivity shocks that are the source of uncertainty in our economies.

We find that the financial autarky economy always behaves very differently to 
the complete markets one, while the equilibrium allocations in the bond economy generally closely approximate those when markets are complete. We also find that for a large portion of the parameter space the behavior of the financial autarky model is closest to the data along most dimensions.

In order to understand our results it useful to note that asset markets have two potential functions in this class of economies. ${ }^{1}$ They allow households to borrow and lend internationally, and they allow them to pool country-specific risk. If productivity shocks are stationary, changes in permanent income following asymmetric shocks are small, implying little need for insurance assets. Provided there exists an asset which permits international borrowing and lending, households can achieve allocations similar to those when markets are complete.

By contrast, the international borrowing and lending function of asset trade is important irrespective of the process for productivity. Thus allocations in the financial autarky model always differ significantly from those when markets are complete. In particular, when households cannot borrow abroad following an increase in domestic productivity, a larger rise in the terms of trade is required to clear markets. This in turn implies different patterns for investment and employment than under the alternative market structures.

Our conclusion is that moving away from the complete markets paradigm can help us understand some previously puzzling features of international data. At the same time, exactly which markets are missing is important. We find that limiting international borrowing is a more successful approach than simply assuming imperfect markets for insurance against country-specific risk.

The paper is organized as follows. In section 2 we describe the model economies. In section 3 we discuss how the models are parameterized and solved. In section 4 the results are presented. Section 5 provides some intuition for the results, and section 6 concludes.

\section{The Economies}

The world consists of two countries, each of which is populated by the same measure of identical, infinitely lived households. Since our three model economies differ only with respect to the menu of internationally traded assets, we first describe their common structure.

In each period $t$ the economy experiences one event $s_{t} \in S$ where $S$ is a possibly infinite set. We denote by $s^{t}$ the history of events up to and including date $t$. The probability at date 0 of any particular history $s^{t}$ is given by $\pi\left(s^{t}\right)$.

\footnotetext{
${ }^{1}$ This distinction is due to Cole [9]
} 
Each household derives utility from consumption, $c_{i}\left(s^{t}\right)$, and from leisure. The amount of labor supplied, $n_{i}\left(s^{t}\right)$, plus leisure cannot exceed the period endowment of time which is normalized to 1 . Period utility for a household in country $i$ after history $s^{t}$ is given by

$$
U\left(c_{i}\left(s^{t}\right), 1-n_{i}\left(s^{t}\right)\right)=\frac{1}{\gamma}\left[c_{i}^{\mu}\left(s^{t}\right)\left(1-n_{i}\left(s^{t}\right)\right)^{1-\mu}\right]^{\gamma} .
$$

Households supply labor and rent capital to perfectly competitive intermediategoods-producing firms ( $i$-firms). Neither labor nor capital is internationally mobile, and households in each country own the capital stock $k_{i}\left(s^{t}\right)$ of that country. $I$-firms in country 1 produce one good called $a$, while those in country 2 produce a different good called $b$.

The $i$-firms' production functions are Cobb-Douglas in domestically located capital and labor:

$$
F\left(z_{i}\left(s^{t}\right), k_{i}\left(s^{t}\right), n_{i}\left(s^{t}\right)\right)=e^{z_{i}\left(s^{t}\right)} k_{i}^{\theta}\left(s^{t}\right) n_{i}^{1-\theta}\left(s^{t}\right)
$$

where $z_{i}\left(s^{t}\right)$ is an exogenous technology shock.

The law of motion for the vector of shocks $z\left(s^{t}\right)=\left[z_{1}\left(s^{t}\right), z_{2}\left(s^{t}\right)\right]$ is given by

$$
z\left(s^{t}\right)=A z\left(s^{t-1}\right)+\varepsilon\left(s^{t}\right)
$$

where $A$ is a $2 \times 2$ matrix, and $\varepsilon\left(s^{t}\right)$ is a $2 \times 1$ vector of independently distributed random variables with variance-covariance matrix $V$.

Let $w_{i}\left(s^{t}\right)$ and $r_{i}\left(s^{t}\right)$ be the wage and rental rate on capital in country $i$ in terms of the intermediate good produced in country $i$. The $i$-firm's static maximization problem in country $i$ after history $s^{t}$ is given by

$$
\begin{gathered}
\max _{k_{i}\left(s^{t}\right), n_{i}\left(s^{t}\right)}\left\{F\left(z_{i}\left(s^{t}\right), k_{i}\left(s^{t}\right), n_{i}\left(s^{t}\right)\right)-w_{i}\left(s^{t}\right) n_{i}\left(s^{t}\right)-r_{i}\left(s^{t}\right) k_{i}\left(s^{t}\right)\right\} \\
\text { subject to } k_{i}\left(s^{t}\right), n_{i}\left(s^{t}\right) \geq 0 .
\end{gathered}
$$

In all three model economies the law of one price holds, since there is a frictionless international spot market on which households can trade intermediate goods. After trading in this spot market and in any active asset markets, households sell their holdings of intermediate goods to domestically located final-goods-producing firms ( $f$-firms). In return households receive the domestic final good which may be consumed or invested. Investment augments the capital stock in the standard way:

$$
k_{i}\left(s^{t+1}\right)=(1-\delta) k_{i}\left(s^{t}\right)+x_{i}\left(s^{t}\right)
$$


where $\delta$ is the depreciation rate and $x_{i}\left(s^{t}\right)$ is the amount of the final good devoted to investment in country $i$.

The $f$-firms are perfectly competitive and produce final goods using intermediate goods $a$ and $b$ as inputs to a constant returns to scale technology: ${ }^{2}$

$$
G_{i}\left(a_{i}\left(s^{t}\right), b_{i}\left(s^{t}\right)\right)= \begin{cases}{\left[\omega_{1} a_{i}\left(s^{t}\right)^{\frac{\sigma-1}{\sigma}}+\left(1-\omega_{1}\right) b_{i}\left(s^{t}\right)^{\frac{\sigma-1}{\sigma}}\right]^{\frac{\sigma}{\sigma-1}},} & i=1 \\ {\left[\left(1-\omega_{1}\right) a_{i}\left(s^{t}\right)^{\frac{\sigma-1}{\sigma}}+\omega_{1} b_{i}\left(s^{t}\right)^{\frac{\sigma-1}{\sigma}}\right]^{\frac{\sigma}{\sigma-1}},} & i=2\end{cases}
$$

where $\sigma$ is the elasticity of substitution between goods $a$ and $b$, and $\omega_{1}>0.5$ determines the extent to which there is a home bias in the composition of domestically produced final goods.

The $f$-firm's static maximization problem in country $i$ after history $s^{t}$ is given by

$$
\begin{gathered}
\max _{a_{i}\left(s^{t}\right), b_{i}\left(s^{t}\right)}\left\{G_{i}\left(a_{i}\left(s^{t}\right), b_{i}\left(s^{t}\right)\right)-q_{i}^{a}\left(s^{t}\right) a_{i}\left(s^{t}\right)-q_{i}^{b}\left(s^{t}\right) b_{i}\left(s^{t}\right)\right\} \\
\text { subject to } a_{i}\left(s^{t}\right), b_{i}\left(s^{t}\right) \geq 0 .
\end{gathered}
$$

where $q_{i}^{a}\left(s^{t}\right)$ and $q_{i}^{b}\left(s^{t}\right)$ are the prices of goods $a$ and $b$ in country $i$ in units of the final good produced in country $i$.

We now describe how the representative households' budget constraints differ across the different market structures.

\section{Complete markets}

One way to complete markets is to assume the existence of a complete set of Arrow securities denominated in units of good $a$. Let $B_{i}\left(s^{t}, s_{t+1}\right)$ be the quantity of bonds purchased by households in country $i$ after history $s^{t}$ that pay one unit of good $a$ in period $t+1$ if and only if the state of the economy is $s_{t+1}$. Let $Q\left(s^{t}, s_{t+1}\right)$ be the price in units of good $a$ of these bonds.

When markets are complete, a consumer's total resources are given by the sum of her factor income and her income from bonds. Resources can be used to acquire the final good from $f$-firms or to purchase new bonds in the international asset market.

Thus the general form of the budget constraint for the representative household in country 1 is

$$
\begin{aligned}
& c_{1}\left(s^{t}\right)+x_{1}\left(s^{t}\right)+q_{1}^{a}\left(s^{t}\right) \sum_{s_{t+1}} Q\left(s^{t}, s_{t+1}\right) B_{1}\left(s^{t}, s_{t+1}\right) \\
= & q_{1}^{a}\left(s^{t}\right)\left(r_{1}\left(s^{t}\right) k_{1}\left(s^{t}\right)+w_{1}\left(s^{t}\right) n_{1}\left(s^{t}\right)\right)+q_{1}^{a}\left(s^{t}\right) B_{1}\left(s^{t-1}, s_{t}\right) .
\end{aligned}
$$

\footnotetext{
${ }^{2}$ The function $G$ is widely used in the trade literature and is often referred to as an Armington aggregator.
} 
The budget constraint for the representative household in country 2 is analogous.

\section{Bond economy}

In this model only a single non-contingent bond is traded. Let $B_{i}\left(s^{t}\right)$ denote the quantity and $Q\left(s^{t}\right)$ the price (in units of good $a$ ) of bonds bought by households in country $i$ after history $s^{t}$. The bond pays one unit of $\operatorname{good}^{3} a$ in period $t+1$ irrespective of the state in $t+1$.

The general form of the budget constraint for the representative household in country 1 is

$$
\begin{aligned}
& c_{1}\left(s^{t}\right)+x_{1}\left(s^{t}\right)+q_{1}^{a}\left(s^{t}\right) Q\left(s^{t}\right) B_{1}\left(s^{t}\right) \\
= & q_{1}^{a}\left(s^{t}\right)\left(r_{1}\left(s^{t}\right) k_{1}\left(s^{t}\right)+w_{1}\left(s^{t}\right) n_{1}\left(s^{t}\right)\right)+q_{1}^{a}\left(s^{t}\right) B_{1}\left(s^{t-1}\right) .
\end{aligned}
$$

\section{Financial autarky}

In the financial autarky model there are no markets for trade in international financial assets. This means that each agent faces the constraint that all goods trade must be quid pro quo.

The general form of the budget constraint for the representative household in country 1 is

$$
c_{1}\left(s^{t}\right)+x_{1}\left(s^{t}\right)=q_{1}^{a}\left(s^{t}\right)\left(r_{1}\left(s^{t}\right) k_{1}\left(s^{t}\right)+w_{1}\left(s^{t}\right) n_{1}\left(s^{t}\right)\right) .
$$

\section{Households' problems}

At date 0 , the expected discounted sum of future period utilities for a household in country $i$ is given by

$$
\sum_{t=0}^{\infty} \sum_{s^{t}} \pi\left(s^{t}\right) \beta^{t} U\left(c_{i}\left(s^{t}\right), 1-n_{i}\left(s^{t}\right)\right)
$$

where $\beta<1$ is the discount factor.

Households choose $c_{i}\left(s^{t}\right) \geq 0$ and $n_{i}\left(s^{t}\right) \in[0,1]$ for all $s^{t}$ and for all $t \geq 0$ to maximize 2.8 subject to the appropriate sequence of budget constraints given by eq. 2.5 or 2.6 or 2.7 , and taking as given initial productivity shocks, initial capital stocks and, if bonds are traded internationally, the initial distribution of bonds.

\footnotetext{
${ }^{3}$ Our solution method is such that the computed equilibrium allocations do not depend on the denomination of the bond. It is easy to show that the denomination of the bond can only have second order effects.
} 


\subsection{Definition of equilibrium}

An equilibrium is a set of prices for all $s^{t}$ and for all $t \geq 0$ such that when households solve their problems taking these prices as given all markets clear.

Market clearing for goods $a$ and $b$ requires that

$$
\begin{aligned}
a_{1}\left(s^{t}\right)+a_{2}\left(s^{t}\right) & =F\left(z_{1}\left(s^{t}\right), k_{1}\left(s^{t}\right), n_{1}\left(s^{t}\right)\right) \\
b_{1}\left(s^{t}\right)+b_{2}\left(s^{t}\right) & =F\left(z_{2}\left(s^{t}\right), k_{2}\left(s^{t}\right), n_{2}\left(s^{t}\right)\right) .
\end{aligned}
$$

Market clearing for final goods requires that

$$
c_{i}\left(s^{t}\right)+x_{i}\left(s^{t}\right)=G_{i}\left(a_{i}\left(s^{t}\right), b_{i}\left(s^{t}\right)\right), \quad i=1,2 .
$$

If markets are complete, bond market clearing requires that

$$
B_{1}\left(s^{t}, s_{t+1}\right)+B_{2}\left(s^{t}, s_{t+1}\right)=0, \quad \forall s_{t+1} \in S .
$$

If there is a single non-contingent bond, bond market clearing requires that

$$
B_{1}\left(s^{t}\right)=B_{2}\left(s^{t}\right) .
$$

\subsection{Additional variables of interest}

Gross domestic product in country $i$ after history $s^{t}$ in units of the final consumption good is denoted $y_{i}\left(s^{t}\right)$, where

$$
y_{i}\left(s^{t}\right)=q_{i}^{a}\left(s^{t}\right) F\left(z_{i}\left(s^{t}\right), k_{i}\left(s^{t}\right), n_{i}\left(s^{t}\right)\right) .
$$

Let $n x\left(s^{t}\right)$ denote net exports for country 1 as a fraction of GDP for country 1:

$$
n x\left(s^{t}\right)=\frac{q_{1}^{a}\left(s^{t}\right) a_{2}\left(s^{t}\right)-q_{1}^{b}\left(s^{t}\right) b_{1}\left(s^{t}\right)}{y_{i}\left(s^{t}\right)} .
$$

Note that in financial autarky, the household budget constraints imply that $n x\left(s^{t}\right)=0$.

Let $\operatorname{ir}\left(s^{t}\right)$ denote the import ratio for country 1, defined as the ratio of imports to non-traded domestic intermediate good production, both measured at base year prices. $^{4}$

$$
\operatorname{ir}\left(s^{t}\right)=\frac{\bar{q} b_{1}\left(s^{t}\right)}{\bar{q} a_{1}\left(s^{t}\right)}=\frac{b_{1}\left(s^{t}\right)}{a_{1}\left(s^{t}\right)}
$$

\footnotetext{
${ }^{4}$ In the model, we take base year prices to be prices in the symmetric steady state. Thus $\bar{q}$ is the steady state price of good $a$ and of good $b$.
} 
Let $p\left(s^{t}\right)$ denote the terms of trade, defined as the price of imports into country 1 relative to exports from country 1 . The $f$-firms first order conditions, together with the functional form for $G$, imply the following relationship between the terms of trade and the import ratio:

$$
p\left(s^{t}\right)=\frac{q_{i}^{b}\left(s^{t}\right)}{q_{i}^{a}\left(s^{t}\right)}=\frac{\omega_{2}}{\omega_{1}} i r\left(s^{t}\right)^{\frac{-1}{\sigma}} \quad i=1,2 .
$$

Let $r x\left(s^{t}\right)$ denote the real exchange rate, defined as the price of consumption in country 2 relative to consumption in country 1 . Since the prices of traded intermediate goods are defined relative to domestic final consumption, applying the law of one price to intermediate goods implies

$$
q_{2}^{a}\left(s^{t}\right) r x\left(s^{t}\right)=q_{1}^{a}\left(s^{t}\right) \quad \text { and } \quad q_{2}^{b}\left(s^{t}\right) r x\left(s^{t}\right)=q_{1}^{b}\left(s^{t}\right)
$$

Thus the real exchange rate is given by

$$
r x\left(s^{t}\right)=\frac{q_{1}^{a}\left(s^{t}\right)}{q_{2}^{a}\left(s^{t}\right)}=\frac{q_{1}^{b}\left(s^{t}\right)}{q_{2}^{b}\left(s^{t}\right)} .
$$

In the appendix we derive the following equilibrium relationship between percentage deviations from the steady state terms of trade, $\widehat{p}$, and percentage deviations from the steady state real exchange rate, $\widehat{r x}$ :

$$
\hat{p}=\left(\frac{1}{2 s-1}\right) \widehat{r x}
$$

where $s \in[0,1]$ denotes the steady state share of locally produced intermediate goods in final goods production. One implication of eq. 2.12 is that the real exchange rate is necessarily less volatile than the terms of trade in our model economies.

\section{Parameter values and computation}

Our benchmark parameter values are reported in table 3. For the purposes of calibration and for computing statistics on international comovements, we identify country 1 as the United States and country 2 as the rest of the world (see the data appendix for details). The main reason for this choice is that bilateral trade between the US and any other single country or even between the US and the European Union (the case considered by BKK [3]) is very small as a fraction of US GDP. When the volume of trade between the two countries in the model is small, the dynamics of the trade balance and of international relative prices have little effect on the dynamics of macroeconomic aggregates. 
Functional forms and most parameter values are taken directly from BKK [3]. However, Pakko [16] and Arvanitis and Mikkola [1] show that the elasticity of substitution between the traded goods is a key parameter in this class of models, while Baxter and Crucini illustrate how the specification of the forcing process for the productivity shocks can affect the role of asset markets. We therefore describe our strategy for selecting values for these parameters.

\subsection{Estimating the process for productivity}

To estimate the process for productivity shocks we need productivity sequences for the US and the rest of the world. Since quarterly data on the capital stock are not available for all countries, we rely on employment data, and identify productivity at date $t$ as $^{5}$

$$
z\left(s^{t}\right)=\log \left(y\left(s^{t}\right)\right)-(1-\theta) \log \left(n\left(s^{t}\right)\right) .
$$

where $y\left(s^{t}\right)$ and $n\left(s^{t}\right)$ are $2 \times 1$ vectors describing real GDP and total employment in the US and in the aggregate of US trading partners. We assume that labor's share of income, $1-\theta$, is 0.64 in both countries.

In table 1 we report our benchmark estimates for the transition matrix $A$ and for the variance covariance matrix $V$. These estimates are similar to those found by BKK for the United States versus Europe, though our process displays smaller spill-overs. ${ }^{6}$

In addition to our benchmark parameterization with spill-overs, we also consider values for $A_{1,2}=A_{2,1}$, the off-diagonal elements of the matrix $A$, ranging from 0 to 0.1 . In order to vary spill-overs without changing the overall persistence of productivity, we simultaneously adjust $A_{11}=A_{22}$ so that the largest eigenvalue remains equal to its value in the benchmark parameterization. Notice that the case in which $A_{1,2}=0$ is the parameterization preferred by Baxter and Crucini [6], while $A_{1,2}=0.088$ is the BKK benchmark choice. We set the correlation between innovations across countries to the estimated value of 0.29 , and set the variance of the productivity innovations for both countries equal to the estimated variance of innovations in the US.

\footnotetext{
${ }^{5}$ Cooley and Prescott [7], note that the capital stock varies very little over the business cycle, so omitting capital should not greatly affect the time series properties of $z$ at business cycle frequencies.

${ }^{6}$ We also estimate the productivity process by first computing and then subtracting a (common across countries) deterministic growth trend from productivity (as in Kollmann [13]). In this case we find that productivity shocks still display high persistence and positively correlated innovations, but we no longer find evidence of spillovers. Thus the long run comovement between productivity in US and in the rest of the world is consistent either with stochastic spillovers or with a common deterministic trend.
} 


\subsection{Estimating the elasticity of substitution}

Irrespective of the international asset market structure or the nature of preferences, the production side of our economies implies the following linear relationship between percentage deviations from the steady state terms of trade, $\widehat{p}$, deviations from steady state output in the two countries, $\hat{y}_{1}$ and $\hat{y}_{2}$, and net exports as a fraction of GDP, $\frac{n x}{y}::^{7}$

$$
\hat{p}=\phi\left[\psi \frac{n x}{y}+\left(\hat{y}_{1}-\hat{y}_{2}\right)\right]
$$

where $\phi=\frac{1}{1+2 s(\sigma-1)}, \psi=\left(\frac{2 s-1}{1-s}\right)$ and $\sigma$ is the elasticity of substitution between good $a$ and good $b$.

Using eq. 2.12, we can rewrite eq. 3.1 in terms of $\widehat{r x}$ rather than $\hat{p}$ :

$$
\widehat{r x}=\phi(2 s-1)\left[\psi \frac{n x}{y}+\left(\hat{y}_{1}-\hat{y}_{2}\right)\right] .
$$

Since we identify the second country in the model with the rest of the world, we set $s$ equal to 1 minus the average ratio of US nominal imports to nominal GDP over the sample period. We then use equation ${ }^{8} 3.2$ to derive a least square estimate for. $\sigma$. The results are reported in table 2 .

Our point estimate for $\sigma$ is 0.90 , which is similar to estimates in previous studies (See Whalley [19] Ch. 5 and Stockman and Tesar [18]) In our benchmark parameterization we set $\sigma=0.90$, but as part of a sensitivity analysis we also experiment with higher and lower values.

\subsection{Solution method}

We solve the models linearizing the equations characterizing equilibrium around the steady state and solving the resulting system of linear difference equations. In the bond economy the law of motion for bonds is not stationary. We make it stationary by imposing a very small quadratic cost on bond holdings.

\footnotetext{
${ }^{7}$ For a derivation of this relationship, see the appendix. Since the output of the intermediate goods sector is normalized to one, and households exhibit home bias in preferences, $s>0.5$ and $\psi>0$.

${ }^{8}$ We choose to estimate $\sigma$ using eq. 3.2 rather than eq. 3.1 since movements in the US terms of trade are strongly influenced by changes in the relative price of oil (see Backus and Crucini [2]) and we do not model oil explicitly.
} 


\section{Results}

\subsection{Benchmark parameter values}

The results of our simulations under the benchmark parameterization are summarized in tables 4 through 6 . Note that for these parameter values there is very little difference between the complete markets and the bond economy models. Baxter and Crucini [6] report the same result for a one-good model, and in light of it we only discuss the complete markets and the financial autarky models in this section.

Both models predict correlations in consumption exceeding those in production whereas the reverse is true in data (see table 6). Moreover the models fail to predict a strong cross-country output correlation. In the data investment and employment both tend to be positively correlated across countries. In the complete markets model, both these correlations are negative. However, they are positive when all international financial markets are closed.

Both models generate too little volatility in trade quantities and international relative prices. However, the percentage standard deviation of the terms of trade in the financial autarky model is twice as large as when markets are complete. ${ }^{9}$ In the data, net exports are counter-cyclical because imports are more strongly procyclical than exports. The complete markets model reproduces these features while the financial autarky model does not.

\subsection{Alternative parameterizations}

Figures 3 and 4 document how some properties of equilibrium allocations vary according to two key parameters: the elasticity of substitution between the domestic and foreign intermediate goods, and the degree to which technology shocks spill over across countries. We focus on a subset of statistics that are particularly sensitive to these parameters. ${ }^{10}$

\section{Varying the elasticity of substitution}

Figure 3 indicates that varying $\sigma$ does not alter the finding from the previous section that there is little difference between the equilibrium allocations emerging in the complete markets and bond economy models. ${ }^{11}$ The figure also illustrates what

\footnotetext{
${ }^{9}$ Backus and Crucini [2] compute a series for the terms of trade that excludes the impact of changes in relative fuel prices. For the US the standard deviation of this series is roughly half that of their raw terms of trade series.

${ }^{10}$ We find that the standard business cycle statistics familiar from closed economy models do not change much across the various parameterizations we consider.

${ }^{11}$ The exceptions to this are (1) that with the low value for $\sigma$ the import ratio and the terms of trade are somewhat more volatile in the bond economy than under complete markets, and (2) that the effect of reducing $\sigma$ on the cross-country consumption correlation differs across the two
} 
BKK [3] have termed the price and quantity anomalies. The price anomaly is that when markets are complete there is no value for $\sigma$ that generates as much volatility in the terms of trade and the import ratio as is observed empirically. The quantity anomaly is that no value for $\sigma$ produces realistic cross country correlations.

By contrast, the equilibrium properties of the financial autarky model are much more sensitive to the choice of $\sigma$ than are those of the other two models. Moreover, closing all international financial markets reduces the gap between the model and the data for most choices for $\sigma$. For example, irrespective of the choice for $\sigma$, the terms of trade is more volatile in the financial autarky autarky economy than in the other economies, and the cross-country correlations for factor supplies and output are higher. Moreover, for values of $\sigma$ between 0.5 and 0.8 , international relative prices in the financial autarky model are roughly as volatile as in the data, and at the same time the cross country correlations of investment, employment and output are strongly positive.

Varying the productivity process

Figure 4 shows that the complete markets and bond economy models look very similar irrespective of the degree of productivity spill-overs. For all variables and for all values for the spill-over term, cross country correlations for the financial autarky model exceed those in the other economies. For all market structures, reducing spill-overs leads to higher cross country correlations in factor supplies and output, and lower correlations for consumption. However, if at least one asset is traded, investment and employment are negatively correlated across countries unless spillovers are very low (and the productivity process is close to a unit root). The volatility of the terms of trade and the import ratio is always higher under financial autarky than in either of the other two economies.

\section{Interpretation}

In this section we explain why the behavior of the financial autarky model differs from the other two models considered. We first analyze (using benchmark parameter values) the response of the world economy to a positive productivity shock in country 1 under the three asset market structures. Subsequently we discuss the effects of changing parameter values.

\subsection{Benchmark parameterization}

Complete Markets

market structures - in the complete markets model the correlation goes down, while in the bond economy model it goes up. This point is stressed by Arvanitis and Mikkola [1]. 
Figures 1 and 2 show that when markets are complete, a positive productivity shock in country 1 leads to an increase in domestic investment and output, and a fall in foreign investment and output. ${ }^{12}$ Since country-specific risks are perfectly insured, consumption rises in both countries. However, the increase in domestic investment is larger than the increase in foreign consumption, and country 1's trade deficit widens. Backus, Kehoe and Kydland describe these responses as a tendency to "make hay where the sun shines" ([3] p.340), meaning that a trade deficit is the result of shifting resources to invest in the temporarily more productive location.

In a world in which there is home bias in consumption, there is an additional reason why a trade deficit occurs. Ceteris paribus, an increase in productivity in country 1 leads to an increase in the world supply of good $a$ relative to good $b$. Abstracting from movements in the trade balance, an increase in output of good $a$ will imply an increase in the terms of trade, since good $b$ becomes relatively scarcer (see eq. 2.11). However, complementarity between intermediate goods in the technology for producing the consumption/investment good implies that is costly to deviate from the steady state mix of the two intermediate inputs or, equivalently, for deviating from the steady state terms of trade. Thus it is optimal to write contracts such that following a positive productivity shock in country 1 , intermediate goods consumption is diverted to country 1 , which is biased towards the now relatively plentiful good $a$. Part of the trade deficit that country 1 runs following the shock can therefore be understood as a way to sustain productive efficiency when the world is characterized by home bias and complementarities in traded goods consumption. ${ }^{13}$ This explains why increases in output and in the trade deficit have offsetting effects on the terms of trade in eq. 3.1.

The increase in the real wage in country 1 following the productivity increase induces households there to increase labor supply, while in country 2 the positive wealth effect of the shock leads to a reduction in labor supply. Lower labor supply implies lower output, and the increase in consumption in country 2 therefore requires a reduction in investment. The fact that investment and employment move in opposite directions following a shock explains why in a simulation the cross-country correlations in employment and investment are negative, and why the correlation in output is less than the correlation in productivity.

As the productivity shock decays, the productivity gap between the two countries

\footnotetext{
${ }^{12}$ Impulse responses for employment are not shown, but look very similar to those for investment.

${ }^{13} \mathrm{As}$ an extreme example, suppose that the steady state ratio of intermediate goods used in country 1 is two units of good $a$ per unit of good $b$. Assume that country two is symmetric with a similar bias towards good $b$. Now if at some date world output of good $a$ is twice the world output of good $b$, a social planner could still achieve the steady state input mix in both countries by having country 1 export nothing and import all of the intermediate goods produced in country 2 .
} 
narrows given spill-overs in the law of motion for $z$. After some date country 2 runs a deficit to permit replacement of its depleted capital stock.

\section{Incomplete Markets}

To understand the effects of closing international asset markets, it is helpful to recall Cole's [9] distinction between the international borrowing and lending function of securities markets on the one hand, and the country-specific risk pooling function on the other.

\section{Bond Economy}

By allowing households to borrow or lend internationally against future income, the presence of a single non-contingent bond helps households to smooth consumption through time, and allows savings to flow to wherever the returns to investment are highest. Because markets for insurance against country-specific risk do not exist in the bond economy, a positive productivity shock in country 1 constitutes a positive relative wealth shock for country 1 . However, under the benchmark parameterization the magnitude of this relative wealth effect is small for two reasons. First, the productivity shock both decays and spills over to the second country. Second, the terms of trade rises following the shock, reflecting greater world scarcity of good $b$ relative to good $a$. This indirectly reduces the relative wealth of households in country 1 , off-setting the direct effect of the productivity shock. Because relative wealth shocks are small, the absence of markets providing insurance against country-specific risk is not very important. This is why the behavior of the bond economy model is very similar to that of the complete markets model for this parameterization. ${ }^{14}$

Financial Autarky

Recall that in the complete markets economy, if country 1 receives a good productivity shock, domestic households borrow internationally to increase investment. Under financial autarky countries cannot run current account deficits. Thus households in country 1 must export more and import less relative to the complete markets model (see the bottom panels of figure 2). This is why exports are more strongly pro-cyclical and imports less strongly pro-cyclical in the financial autarky economy.

The fact that all trade in the financial autarky economy has to be quid pro $q u o$ also means that following the shock it is impossible to concentrate final goods production in country 1 , the country biased towards good $a$ which is now more abundant. Consequently, we observe a larger fall in the import ratio and a larger increase in the terms of trade relative to the other economies (in terms of eq. 3.1, the rise in $\hat{p}$ must be larger following an increase in $\hat{y}_{1}$ because no offsetting fall in

\footnotetext{
${ }^{14}$ Constantinides and Duffie [11] make a similar point in explaining why with a stationary process for income, heterogenous consumers are able to come close to the complete markets rule of complete risk sharing even when they are allowed to trade in just one security.
} 
$n x / y$ is possible). In fact, the percentage increase in the terms of trade at the date of the shock is now greater than the percentage change in relative productivities. Thus, under financial autarky, a positive productivity shock in country 1 reduces the relative value of country 1 's output. ${ }^{15}$

The fact that productivity shocks imply larger movements in the terms of trade is related to our finding that cross-country correlations are larger under financial autarky than in the other economies. Following a positive shock, households in country 1 increase consumption, investment and employment by less under financial autarky than in the complete markets economy, since the large increase in the terms of trade reduces the market value of their output and thus their income. At the same time, households in country 2 increase consumption by more under financial autarky, and increase investment (even though country 2 is now the less productive country) to take advantage of the terms of trade movement in their favor.

As the productivity increase in country 1 dissipates and spills over to country 2 , the complete markets economy impulse responses show rising investment in country 2 , which eventually leads to a trade surplus for country 1 . We argued above that the change in the terms of trade immediately following a country-specific shock is smaller under complete markets than under financial autarky because a countercyclical current account mitigates the effect of the shock on relative prices. When the sign of net exports changes as the productivity shock decays, the same reasoning accounts for why the value for the terms of trade now becomes lower under financial autarky than with complete markets (see eq. 3.1).

\subsection{Varying the elasticity of substitution}

Reducing the elasticity of substitution between traded goods increases the volatility of the terms of trade in all three economies since deviations from the steady state mix of intermediate inputs are associated with larger changes in their relative price (see eq. 2.11) The intuition is that greater complementarity is associated with a larger return to relative scarcity.

However, in discussing the complete markets model, BKK ([3] p.348) note that "choosing a small value of $\sigma$ "resolves" the price variability anomaly only by making the variability of $b_{1} / a_{1}$ much smaller than it is in the data". The volatility of the import ratio is inversely related to $\sigma$ because as the degree of substitutability between traded goods is reduced, there is a greater incentive to avoid large deviations from the optimal mix of intermediate goods in final goods production. One way this is accomplished is through using more inter-temporal borrowing and lending to

\footnotetext{
${ }^{15}$ The fact that the terms of trade is more volatile in the financial autarky economy indicates that on average more units of intermediate inputs are required to produce the same amount of final goods. This is a real cost of missing asset markets.
} 
concentrate production in the country biased towards whichever intermediate good is temporarily more abundant.

The fact that the volatility of the import ratio falls as $\sigma$ is reduced partially offsets the direct effect of reducing $\sigma$ on the volatility of the terms of trade. Thus movements in the terms of trade remain small relative to those seen in the data. The similarity between the behavior of the complete markets and the bond economy models again follows from the fact that the magnitude of changes in relative wealth following country specific productivity shocks is small given the law of motion for the shocks.

When no assets are traded internationally, a lower value for $\sigma$ means that following a positive shock in country 1 , domestic households trading on the spot market have to give up more exports to receive same amount of imports, since relative prices adjust to reflect lower substitutability. Thus in the financial autarky model, households in country 1 must export more and import less relative to the benchmark parameterization in order to achieve balanced trade. This means that the import ratio falls by more with a lower value for $\sigma$ than in the same model under the benchmark parameterization. Thus reducing $\sigma$ increases the volatility of the import ratio in the financial autarky model, contrary to the pattern for the complete markets economy. This is why reducing substitutability leads to a larger percentage increase in the volatility of the terms of trade in the financial autarky model, and also explains why the financial autarky economy can generate both high volatility of the terms of trade and high volatility of the import ratio for low values of $\sigma$.

Since the increase in the terms of trade is larger under financial autarky, an increase in productivity in country 1 has a stronger negative effect on country 1's relative wealth than in the bond economy model. Since leisure and consumption are both normal goods, we should expect this relative wealth effect to lead to increased consumption and reduced work effort in country 2, ceteris paribus. Indeed as $\sigma$ is reduced the size of the increase in consumption in country 2 relative to the increase in country 1 rises. Thus the cross country correlation of consumption rises. On the other hand, for low values for $\sigma$, the wealth effect on labor supply is outweighed by the effects of changes in the terms of trade. Following a positive shock in country 1 , the increase in the relative price of good $b$ accounts for why households increase labor supply in country 2, and thus why a positive correlation between employment in the two countries is observed. The employment responses explain why the cross-country GDP correlation is inversely related to $\sigma$.

\subsection{Varying spill-overs in the productivity process}

When productivity shocks spill-over across borders, a good productivity shock in country 1 today signals higher productivity in country 2 in the future. Abstracting 
from the effects of movements in the terms of trade, households in country 1 have an incentive to immediately increase investment and labor supply, while households in country 2 have an incentive to lend abroad rather than invest domestically, and to reduce work effort until the shock spills over. This is why bigger spill-overs mean lower cross country correlations for factor supplies and output. At the same time, bigger spill-overs mean smaller changes in relative wealth, and closer comovement in consumption. Reducing the extent of spill-overs therefore reduces the gap between the models and the data in all these dimensions.

The fact that the financial autarky model consistently generates higher cross country correlations than the other economies is once again explained by the fact that the rise in the terms of trade following a shock in country 1 is much greater than in the complete markets model. Households in the relatively less productive country have an incentive to work harder and increase investment since they are paid in units of the scarce and valuable intermediate good. This works to offset the effect of spill-overs, and explains why cross-country correlations are higher in the financial autarky economy.

For a given value for $\sigma$, the magnitude of a relative wealth shock in models without insurance markets is greater the smaller are spill-overs, since smaller spill-overs mean more permanent changes in relative productivities and relative prices. When productivity shocks are near unit root with no spill-overs, we would therefore expect large differences between the behavior of the complete markets model (where changes in relative wealth can be insured against) and the models with incomplete asset markets. While this is certainly the case for the financial autarky model, we do not observe large differences between the complete markets and bond economy models. This result is peculiar to our particular choice for the elasticity of substitution. In particular, given an elasticity close to 1 , movements in the terms of trade almost exactly offset changes in relative productivity. ${ }^{16}$ Thus the overall wealth effects of productivity changes in the complete markets and bond economy models are similar.

\section{Conclusions}

We have examined the importance of opportunities for international borrowing and lending for a two-country two-good world in which both capital and labor are endogenous. Lewis [15] has shown that capital market restrictions can help explain the apparent lack of international consumption risk sharing. In a richer framework we find that a total absence of international asset markets can help to explain the

\footnotetext{
${ }^{16}$ For an endowment economy, Cole and Obstfeld [10] show that given a unitary elasticity of substitution these two effects do in fact exactly offset each other.
} 
cross-country GDP, employment and investment correlations typically observed in data. Moreover the volatilities of trade-related statistics in the financial autarky model are much higher than in the complete markets model, and are of a similar order of magnitude to those for the US.

Our results are sensitive to the choice for $\sigma$, the elasticity of substitution between the home and the foreign intermediate good, and to the extent to which productivity shocks spill over across national borders. However, we find that irrespective of the choice for these parameters, ruling out international asset trade narrows the gap between the model and the data. For example, even if $\sigma$ is treated as a free parameter, the complete markets and single bond models are unable to simultaneously generate realistic cross country correlations, and at the same time produce sufficient volatility in both the terms of trade and trade volumes. The financial autarky model implies a reasonable fit with the data along these dimensions for a range of values for $\sigma$ between 0.5 and 1 .

A general shortcoming of this class of models is that the production structure implies a linear relationship between the real exchange rate and the terms of trade. We show that the real exchange rate is necessarily less volatile than the terms of trade in the models whereas the reverse is true of the data.

A criticism specific to the financial autarky model is that it does not generate any international borrowing and lending. Nevertheless we believe that the model provides a useful starting point for studying the macroeconomic effects of ongoing growth in international financial markets. In the first decade of our sample (19731983), the average absolute value for the ratio of the US trade balance to US GDP was $0.6 \%$, while by the last decade (1988-1998), the corresponding value had risen to $1.1 \%$. Across the same two periods, the correlations of US investment and employment with the same variables in the rest of the world fell from 0.68 and 0.70 to -0.12 and 0.01 respectively, while the output correlation fell from 0.78 to 0.26 . In future work we plan to quantitatively investigate the extent to which these changes in the international business cycle are due to increased opportunities for international borrowing and lending. Our comparison of different asset market structures suggests that, holding constant the underlying shock structure, high cross-country correlations are to be expected if financial autarky is a reasonable approximation, while lower correlations should be observed if the complete markets or bond economy model is the more relevant benchmark.

To conclude, this paper suggests that the extent of opportunities for international inter-temporal borrowing and lending is important and relevant for future research. Important in that if we eliminate all such opportunities the resulting equilibrium allocations and prices behave very differently than when markets are complete. Relevant because the financial autarky regime reproduces many aspects of the data better than other asset structures. 


\section{References}

[1] Arvanitis, A.V. and A. Mikkola, 1996, "Asset market structure and international trade dynamics", AEA Papers and Proceedings 86, 67-70.

[2] Backus, D.K. and M.J. Crucini, 2000, "Oil prices and the terms of trade", Journal of International Economics 50, 185-213.

[3] Backus, D.K., P.J. Kehoe, and F.E. Kydland, 1995, "International business cycles: theory and evidence", in T. Cooley ed., Frontiers of Business Cycle Research, Princeton University Press, Princeton, 331-356.

[4] Backus, D.K., P.J. Kehoe, and F.E. Kydland, 1994, "Dynamics of the trade balance and the terms of trade: the J-curve?", American Economic Review 84, 84-103.

[5] Baxter, M., 1995, "International trade and business cycles", NBER Working Paper No. 5025.

[6] Baxter, M. and M.J. Crucini, 1995, "Business cycles and the asset structure of foreign trade", International Economic Review 36, 821-854.

[7] Cooley T., E. Prescott, 1995, "Economic Growth and Business Cycles",in T. Cooley ed., Frontiers of Business Cycle Research, Princeton University Press, Princeton, 1-38

[8] Chari, V.V., P.J. Kehoe, and E.R. McGrattan, 1998, "Can Sticky Price Models Generate Volatile and Persistent Real Exchange Rates?", Federal Reserve Bank of Minneapolis Staff Report 223.

[9] Cole, H.L., 1993, "The macroeconomic effects of world trade in financial assets", Federal Reserve Bank of Minneapolis Quarterly Review 17.

[10] Cole, H.L. and M. Obstfeld, 1991, "Commodity trade and international risk sharing: How much do financial markets matter?", Journal of Monetary Economics 28, 3-24.

[11] Constantinides, G.M. and D. Duffie, 1996, "Asset pricing with heterogeneous households", Journal of Political Economy 104, 219-240.

[12] Kehoe P.J. and F. Perri, 199 , "International business cycles with endogenous incomplete markets", Federal Reserve Bank of Minneapolis, Staff Report 265. 
[13] Kollman, R., 1996 "Incomplete asset markets and the cross-country consumption correlation puszzle", Journal of Economic Dynamics and Control 20, 945961.

[14] Leahy M.P., 1998, "New summary measures of the foreign exchange value of the dollar", Federal Reserve Bulletin, October.

[15] Lewis, K.K., 1996, "What can explain the apparent lack of international consumption risk sharing?", Journal of Political Economy 104, 267-297.

[16] Pakko, M.R., 1997, "International risk sharing and low cross-country consumption correlations: are they really inconsistent", Review of International Economics 5, 386-400.

[17] Pakko, M.R., 1998, "Characterizing cross-country consumption correlations", Reveiw of Economics and Statistics 80, 169-174.

[18] Stockman, A.C., and L.L. Tesar, 1995, "Tastes and technology in a two-country model of the business cycle: explaining international comovements", American Economic Review 85, 168-185.

[19] Whalley, J., 1985, Trade Liberalization Among Major World Trading Areas, MIT Press, Cambridge, MA. 


\section{Appendix}

In this appendix we derive the equilibrium relations between international prices and quantities implied by a log-linearized version of our model. Note that the relations developed here depend only on the production structure of the economy and are independent of both the specification of preferences and the international asset market structure. Throughout the appendix, a bar on a variable denotes the steady state value, while a hat denotes the percentage deviation from the steady state value. We suppress both the dependence of variables on the state $s^{t}$, and the arguments of the functions $G_{i}\left(a_{i}, b_{i}\right), G_{i a}\left(a_{i}, b_{i}\right), G_{i b}\left(a_{i}, b_{i}\right)$. In other respects, the notation is the same as in the main body of the paper.

Let $s$ denote the steady state share of locally produced intermediate goods in final goods production.

Linearizing the $f$-firm first order conditions gives

$$
\begin{array}{rlrl}
\hat{G}_{i a} & =\hat{q}_{i}^{a} & i=1,2 \\
\hat{G}_{i b} & =\hat{q}_{i}^{b} & i=1,2
\end{array}
$$

Let $y_{i}=F\left(z_{i}, k_{i}, n_{i}\right)$ denote $i$-firms' output in country $i$. Linearizing 2.9 and 2.10, the market clearing conditions for goods $a$ and $b$, gives

$$
\begin{aligned}
s \hat{a}_{1}+(1-s) \hat{a}_{2} & =\hat{y}_{1} \\
(1-s) \hat{b}_{1}+s \hat{b}_{2} & =\hat{y}_{2}
\end{aligned}
$$

Marginal productivities of $f$-firms can be rewritten as

$$
\begin{array}{rlrl}
\sigma \hat{G}_{i, a} & =\hat{G}_{i}-\hat{a}_{i} & i=1,2 \\
\sigma \hat{G}_{i, b} & =\hat{G}_{i}-\hat{b}_{i} & i=1,2
\end{array}
$$

Total production of $f$-firms can be written as

$$
\begin{aligned}
& \hat{G}_{1}=s \hat{a}_{1}+(1-s) \hat{b}_{1} \\
& \hat{G}_{2}=(1-s) \hat{a}_{2}+s \hat{b}_{2}
\end{aligned}
$$

Movements in the terms of trade and the real exchange rate are given by

$$
\begin{aligned}
\widehat{p} & =\hat{q}_{1}^{b}-\hat{q}_{1}^{a}=\hat{q}_{2}^{b}-\hat{q}_{2}^{a} \\
\widehat{r x} & =\hat{q}_{1}^{a}-\hat{q}_{2}^{a}=\hat{q}_{1}^{b}-\hat{q}_{2}^{b}
\end{aligned}
$$

Substitute 7.5-7.8 and 7.10 into 7.1-7.2 to obtain

$$
\begin{aligned}
(1-s)\left(\hat{b}_{1}-\hat{a}_{1}\right) & =\sigma \hat{q}_{1}^{a} \\
-s\left(\hat{b}_{1}-\hat{a}_{1}\right) & =\sigma q_{1}^{b}=\sigma\left(\widehat{r x}+\hat{q}_{2}^{b}\right) \\
s\left(\hat{b}_{2}-\hat{a}_{2}\right) & =\sigma q_{2}^{a}=\sigma\left(\hat{q}_{1}^{a}-\widehat{r x}\right) \\
-(1-s)\left(\hat{b}_{2}-\hat{a}_{2}\right) & =\sigma \hat{q}_{2}^{b}
\end{aligned}
$$


Next, solving for $\left(\hat{b}_{1}-\hat{a}_{1}\right)$ in 7.11 and 7.12 and for $\left(\hat{b}_{2}-\hat{a}_{2}\right)$ in 7.13 and 7.14 we have

$$
\begin{aligned}
-\frac{s}{1-s} \hat{q}_{1}^{a} & =\widehat{r x}+\hat{q}_{2}^{b} \\
\frac{s}{1-s} \hat{q}_{2}^{b} & =\widehat{r x}-\hat{q}_{1}^{a}
\end{aligned}
$$

Combining 7.15 and 7.16 gives

$$
\begin{aligned}
\hat{q}_{1}^{a} & =\frac{(s-1)}{2 s-1} \widehat{r x} \\
\hat{q}_{2}^{b} & =\frac{(1-s)}{2 s-1} \widehat{r x} \\
\hat{p} & =\left(\widehat{r x}+\hat{q}_{2}^{b}-\hat{q}_{1}^{a}\right)=\frac{1}{2 s-1} \widehat{r x}
\end{aligned}
$$

Equation 7.19 reveals the linear relationship between movements in the real exchange rate and movements in the terms of trade. Also note that, since $s$ is between 0 and 1 , the variance of the real exchange rate is always less than the variance of the terms of trade; as a special case when the import share is equal to $1 / 2$ the real exchange rate is fixed.

From $7.11,7.17,7.14$ and 7.18 we get

$$
\begin{aligned}
& \left(\hat{b}_{1}-\hat{a}_{1}\right)=\frac{-\sigma}{2 s-1} \widehat{r x} \\
& \left(\hat{b}_{2}-\hat{a}_{2}\right)=\frac{-\sigma}{2 s-1} \widehat{r x} .
\end{aligned}
$$

Using 7.3, 7.4, 7.20, and 7.21, we can solve for $\hat{a}_{2}$ and $\hat{b}_{1}$ as functions of $\widehat{r x}, \hat{y}_{1}$ and $\hat{y}_{2}$.

$$
\begin{aligned}
& \hat{b}_{1}=\frac{-s \sigma}{(2 s-1)^{2}} \widehat{r x}+\left(\frac{1}{2 s-1}\right)\left(s \hat{y}_{1}-(1-s) \hat{y}_{2}\right) \\
& \hat{a}_{2}=\frac{s \sigma}{(2 s-1)^{2}} \widehat{r x}+\left(\frac{1}{2 s-1}\right)\left(s \hat{y}_{2}-(1-s) \hat{y}_{1}\right)
\end{aligned}
$$

Taking a first order approximation around the deterministic steady-state, we get the following expression for the ratio of the trade balance to GDP at current prices:

$$
\frac{n x}{y}=(1-s)\left(\hat{a}_{2}-\hat{b}_{1}-\hat{p}\right) .
$$

Substituting into this expression from 7.22 and 7.23 , and using 7.19 we get

$$
\hat{p}=\phi \psi \frac{n x}{y}-\phi\left(\hat{y}_{2}-\hat{y}_{1}\right)
$$


where $\phi=\frac{1}{1+2 s(\sigma-1)}$ and $\psi=\left(\frac{2 s-1}{1-s}\right)$

\section{Data Appendix}

The data series for US GDP, consumption, investment and employment are all from OECD Main Economic Indicators (MEI), and they are, respectively, Gross Domestic Product, Private plus Government Final Consumption Expenditure, Gross Fixed Capital Formation (all at constant prices) and the Civilian Employment Index. The series for the US real exchange rate is a trade-weighted measure of the real value of the US dollar reported by the Board of Governors (Broad Index) ${ }^{17}$. The series for the terms of trade is the ratio of import prices (imports at current prices over imports at constant prices) over export prices (exports at current prices over exports at constant prices). The series for imports and exports at current and constant prices are from the OECD Quarterly National Accounts. For GDP, consumption and investment in the rest of the world, we constructed an aggregate of Canada, Japan, and 15 European countries (Austria, Belgium, Denmark, Finland, France, Germany, Greece, Ireland, Italy, Norway, Netherlands, Portugal, Spain, Sweden and the United Kingdom). The original series are from the OECD-MEI, the same source we used for the US. We aggregated to create a single fictional non-US country using PPP exchange rates. Since consistent series for employment for all countries are not available, the employment series for the rest of the world is an aggregate of employment in Canada, Japan and 9 European Countries (Austria, Finland, France, Germany, Italy, Norway, Spain, Sweden and the United Kingdom). The series for each country is the Civilian Employment Index from the OECD MEI, and weights proportional to 1995 populations are used to aggregate.

The dataset is available at www.stern.nyu.edu/ fperri/research.

\footnotetext{
${ }^{17}$ For details on the construction of the series see Leahy [14]
} 
Estimating system:

$$
\left[\begin{array}{l}
z_{1, t} \\
z_{2, t}
\end{array}\right]=\left[\begin{array}{ll}
A_{11} & A_{12} \\
A_{21} & A_{22}
\end{array}\right]\left[\begin{array}{l}
z_{1, t-1} \\
z_{2, t-1}
\end{array}\right]+\left[\begin{array}{l}
\varepsilon_{1, t} \\
\varepsilon_{2, t}
\end{array}\right] \quad\left[\begin{array}{l}
\varepsilon_{1, t} \\
\varepsilon_{2, t}
\end{array}\right]=N(0, V)
$$

Estimates:

benchmark (no detrending)

$$
\begin{aligned}
& A_{11}=A_{22}=\underset{(0.007)}{0.970} \\
& A_{21}=A_{12}=\underset{(0.008)}{0.025} \\
& \sigma_{\varepsilon_{1}}=0.0073, \quad \sigma_{\varepsilon_{2}}=0.0044 \\
& \operatorname{corr}\left(\varepsilon_{1}, \varepsilon_{2}\right)=0.290
\end{aligned}
$$

productivity series detrended

$$
\begin{aligned}
& A_{11}=A_{22}=\underset{(0.007)}{0.960} \\
& A_{21}=A_{12}=\underset{(0.008)}{0.000} \\
& \sigma_{\varepsilon_{1}}=0.0072, \quad \sigma_{\varepsilon_{2}}=0.0044 \\
& \operatorname{corr}\left(\varepsilon_{1}, \varepsilon_{2}\right)=0.280
\end{aligned}
$$

Estimates are obtained using the Seemingly Unrelated Regression Procedure (SURE) for systems of equations. Symmetry is imposed at the estimation stage. Standard errors are in parentheses. The sample for the data series is $1973.1-1998.4$.

\section{Table 2: Estimate of the elasticity of substitution}

Estimating equation:

\begin{tabular}{|c|c|c|}
\hline Preferences & $\begin{array}{l}\text { Discount Factor } \\
\text { Consumption Share } \\
\text { Risk Aversion }\end{array}$ & $\begin{array}{l}\beta=0.99 \\
\mu=0.34 \\
1-\gamma=2\end{array}$ \\
\hline Technology & $\begin{array}{l}\text { Capital share } \\
\text { Depreciation Rate } \\
\text { Import share of } i \text {-firms (for calibrating } \omega_{1} \text { ) } \\
\text { Std. dev. of innovations to productivity } \\
\text { Correlation of innovations to productivity } \\
\text { Productivity transition matrix }\end{array}$ & $\begin{array}{l}\theta=0.36 \\
\delta=0.025 \\
i s=0.15 \\
\sigma_{\varepsilon_{1}}=\sigma_{\varepsilon_{2}}=0.0073 \\
\operatorname{corr}\left(\varepsilon_{1}, \varepsilon_{2}\right)=0.290 \\
\mathrm{~A}=\left[\begin{array}{ll}0.970 & 0.025 \\
0.025 & 0.970\end{array}\right]\end{array}$ \\
\hline & Elasticity of substitution between $a$ and $b$ & $\sigma=0.90$ \\
\hline
\end{tabular}

$$
\hat{r} x_{t}=\frac{(2 s-1)}{1+2 s(\tilde{\sigma}-1)}\left[\left(\frac{2 s-1}{1-s}\right) \frac{n x_{t}}{y_{t}}+\hat{y}_{1, t}-\hat{y}_{2, t}\right]+\eta_{t}
$$

where $\mathrm{s}=0.897$

Estimate for $\sigma$

$$
\tilde{\sigma}=\underset{(0.12)}{0.90} \quad \begin{aligned}
& \mathrm{R} \text {-squared of } \\
& \text { regression }
\end{aligned} \quad \mathrm{R}^{2}=0.38
$$

$\eta_{\mathrm{t}}$ is a normally distributed disturbance capturing measurement error and non modeled shocks. The estimate for $\sigma$ is obtained using ordinary least squares and delta method. The Newey-West heteroskedasticity consistent standard error is in parentheses. The sample for the data series is 1973.1-1998.4.

\section{Table 3: Benchmark parameters}


Table 4: Volatilities

\begin{tabular}{|c|c|c|c|c|c|c|c|c|}
\hline \multirow[b]{2}{*}{ Economy } & \multirow{2}{*}{$\begin{array}{c}\% \text { std dev } \\
\mathrm{y}\end{array}$} & \multicolumn{3}{|c|}{$\% \frac{\% \text { std dev }}{\% \text { std dev of } y}$} & \multicolumn{4}{|c|}{$\%$ std dev } \\
\hline & & $\mathrm{c}$ & $\mathrm{x}$ & $\mathrm{n}$ & ex & $\mathrm{im}$ & $\mathrm{nx}$ & ir \\
\hline U.S. Data & 1.67 & 0.81 & 2.84 & 0.66 & 3.94 & 5.42 & 0.45 & 4.07 \\
\hline Complete markets & 1.21 & 0.53 & 2.74 & 0.31 & 0.99 & 0.99 & 0.20 & 0.70 \\
\hline Bond economy & 1.21 & 0.52 & 2.73 & 0.32 & 0.96 & 0.96 & 0.19 & 0.76 \\
\hline Financial autarky & 1.18 & 0.51 & 2.04 & 0.28 & 1.29 & 1.18 & 0.00 & 1.51 \\
\hline
\end{tabular}

Table 5: Correlations with output

\begin{tabular}{|c|c|c|c|c|c|c|c|c|}
\hline \multirow[b]{2}{*}{ Economy } & \multicolumn{8}{|c|}{ correlation between } \\
\hline & $\mathrm{c}, \mathrm{y}$ & $\mathrm{x}, \mathrm{y}$ & $\mathrm{n}, \mathrm{y}$ & ex,y & im,y & $\mathrm{nx}, \mathrm{y}$ & $\mathrm{p}, \mathrm{y}$ & $\mathrm{rx}, \mathrm{y}$ \\
\hline U.S. Data & 0.86 & 0.95 & 0.87 & 0.32 & 0.81 & -0.49 & -0.24 & 0.13 \\
\hline Complete markets & 0.96 & 0.96 & 0.97 & 0.55 & 0.89 & -0.64 & 0.65 & 0.65 \\
\hline Bond economy & 0.95 & 0.96 & 0.97 & 0.59 & 0.86 & -0.65 & 0.65 & 0.65 \\
\hline Financial autarky & 0.92 & 0.99 & 0.99 & 1.00 & 0.15 & 0.00 & 0.65 & 0.65 \\
\hline
\end{tabular}

Table 6: Cross country correlations and international relative price volatility

\begin{tabular}{|c|c|c|c|c|c|c|}
\hline \multirow[b]{2}{*}{ Economy } & \multicolumn{4}{|c|}{ correlation between } & \multicolumn{2}{|c|}{$\%$ std dev } \\
\hline & $\mathrm{y}_{1}, \mathrm{y}_{2}$ & $\mathrm{c}_{1}, \mathrm{c}_{2}$ & $\mathrm{x}_{1}, \mathrm{x}_{2}$ & $\mathrm{n}_{1}, \mathrm{n}_{2}$ & $\mathrm{p}$ & $\mathrm{rx}$ \\
\hline Data & 0.58 & 0.36 & 0.30 & 0.42 & 2.99 & 3.73 \\
\hline Complete markets & 0.18 & 0.65 & -0.29 & -0.14 & 0.78 & 0.55 \\
\hline Bond economy & 0.17 & 0.68 & -0.29 & -0.17 & 0.84 & 0.59 \\
\hline Financial autarky & 0.24 & 0.85 & 0.35 & 0.14 & 1.68 & 1.18 \\
\hline
\end{tabular}

The data statistics in tables 4-5 are calculated from US time series for the period 1973.1 1998.4. The data statistics for international correlations refer to the correlation of US series with series for an aggregate of the rest of the world for the period 1973.1 1998.4 (see the data appendix for details). All series have been logged (except net exports) and Hodrick-Prescott filtered with a smoothing parameter of 1600. The statistics from the model are the averages of 100 simulations each 104 periods long. Standard errors are available upon request. 
Figure 1: Impulse responses for 1\% productivity shock in country 1. Productivity, output and consumption
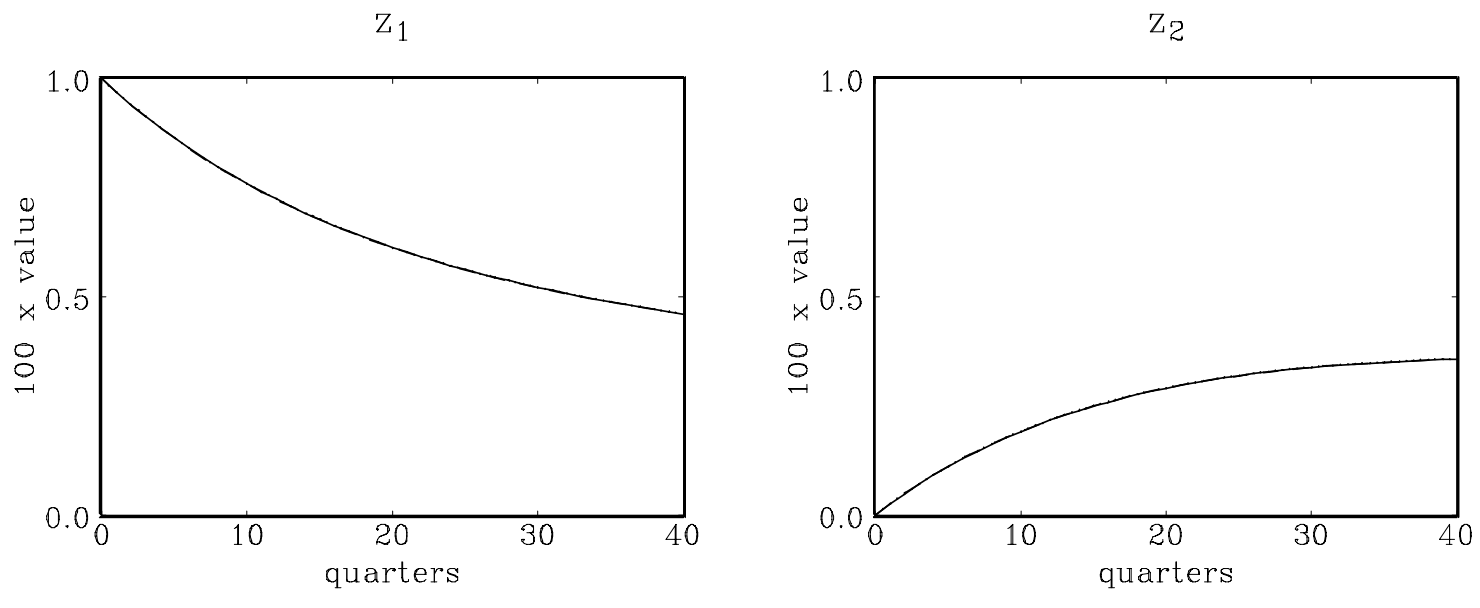

$\mathrm{y}_{1}$
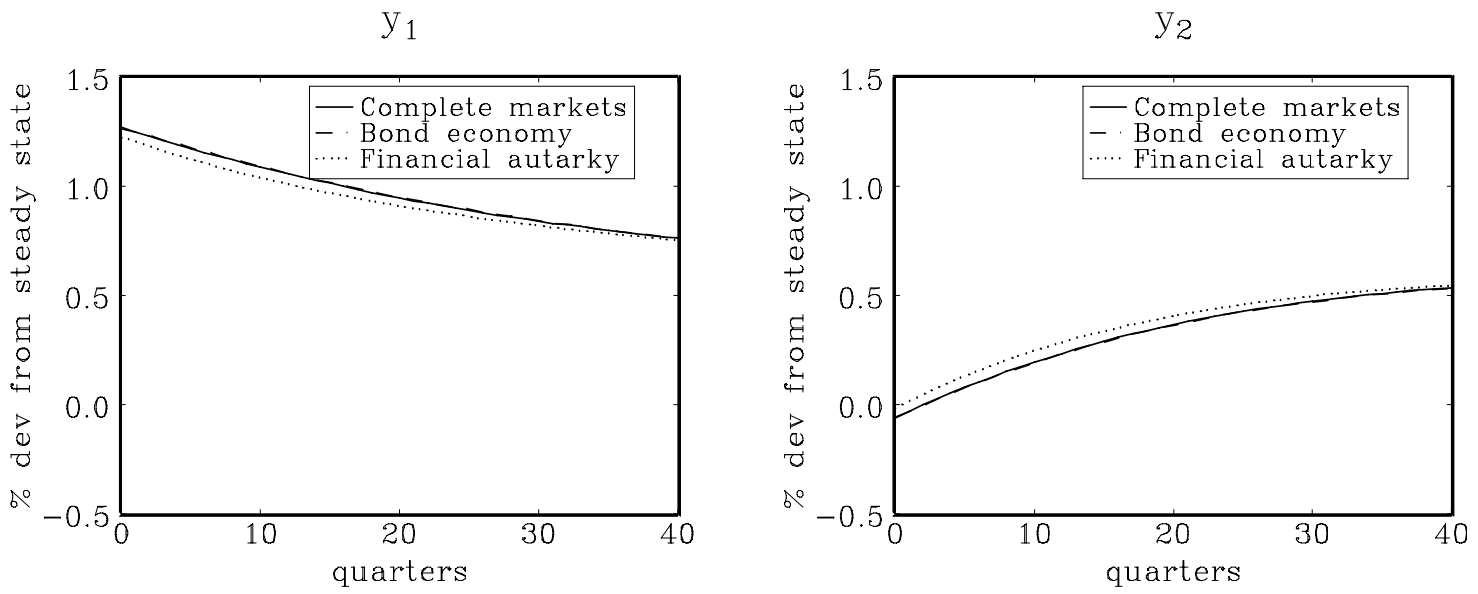

$c_{1}$
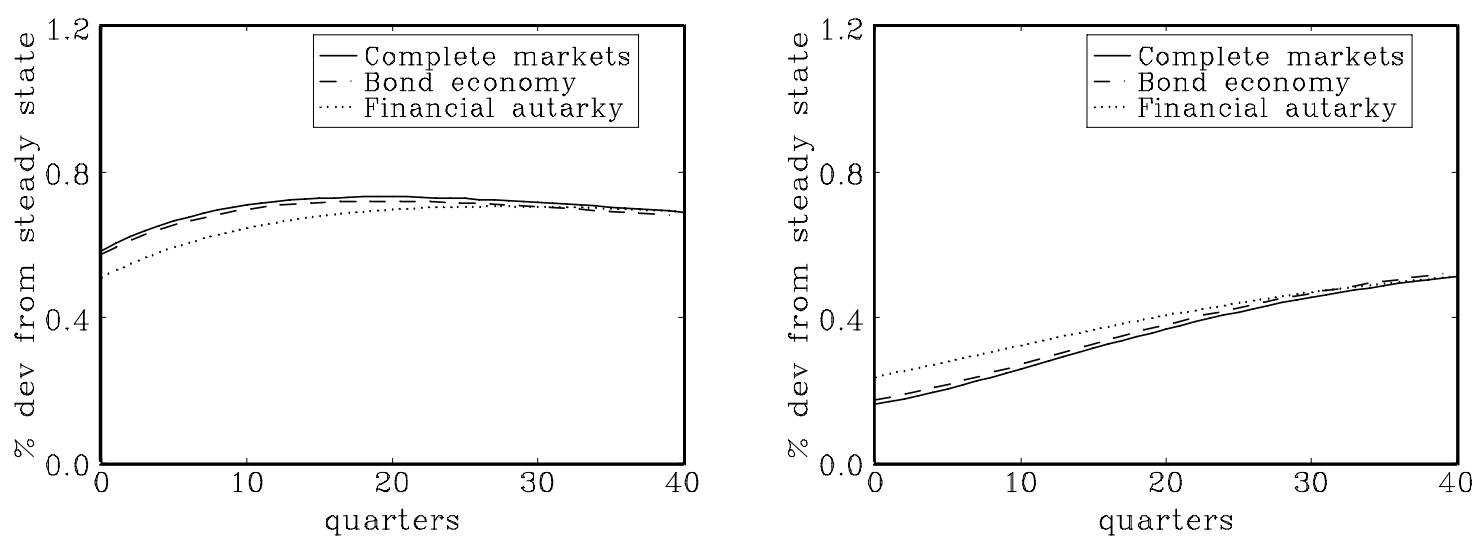
Figure 2: Impulse responses for 1\% productivity shock in country 1. Investment and trade variables
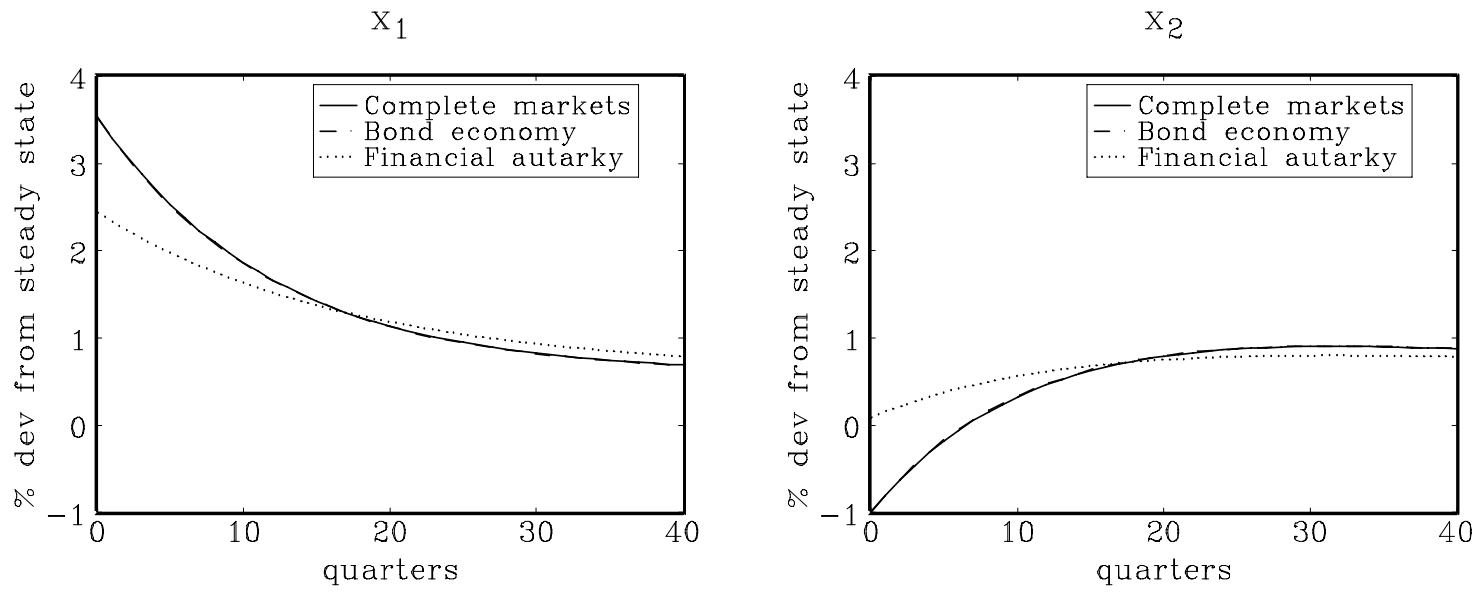

terms of trade $(p)$

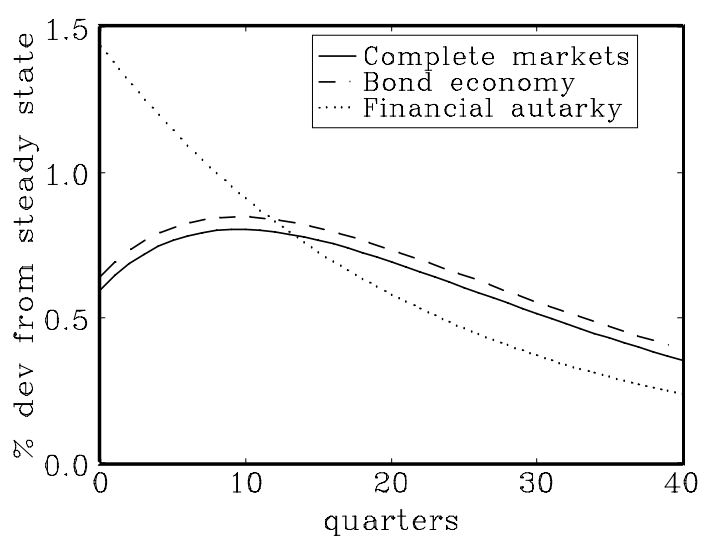

net exports $\left(a_{2}-p_{1}\right)$

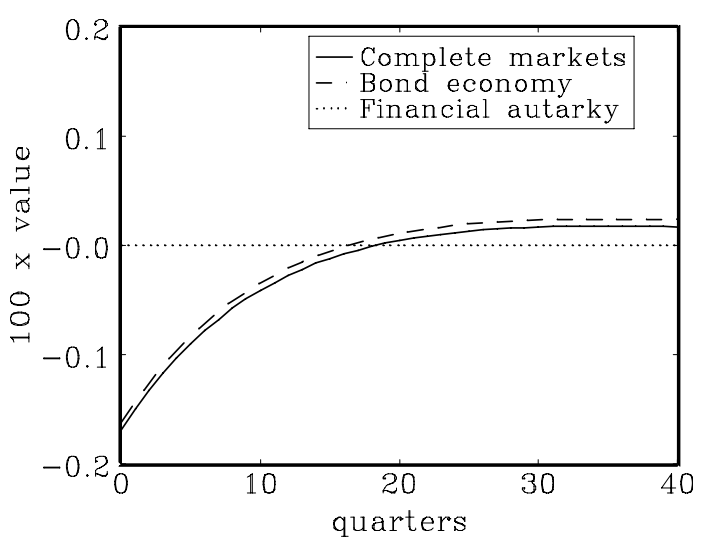

exports $\left(a_{2}\right)$

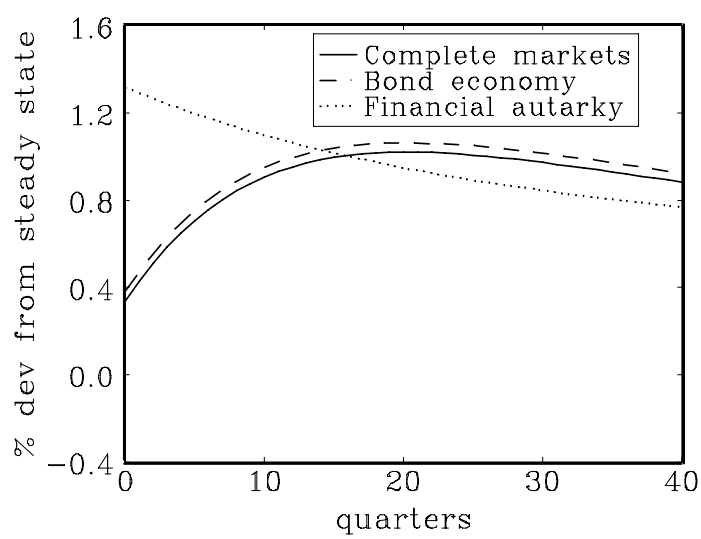

imports $\left(b_{1}\right)$

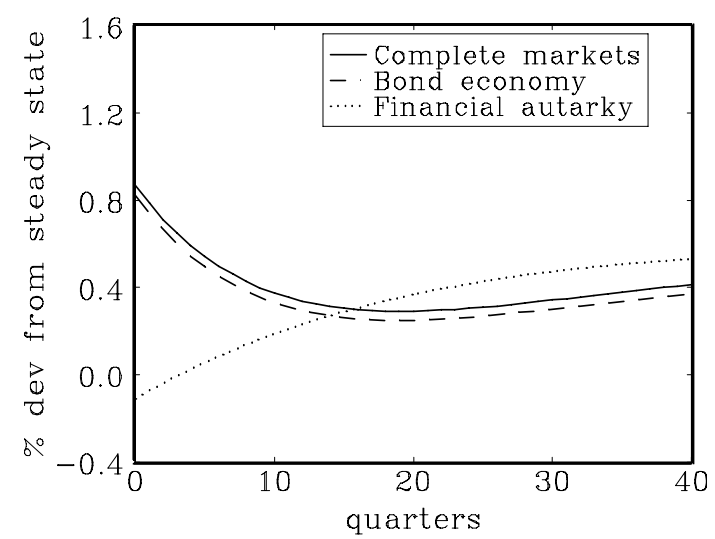


Figure 3: Varying $\sigma$, the elasticity of substitution
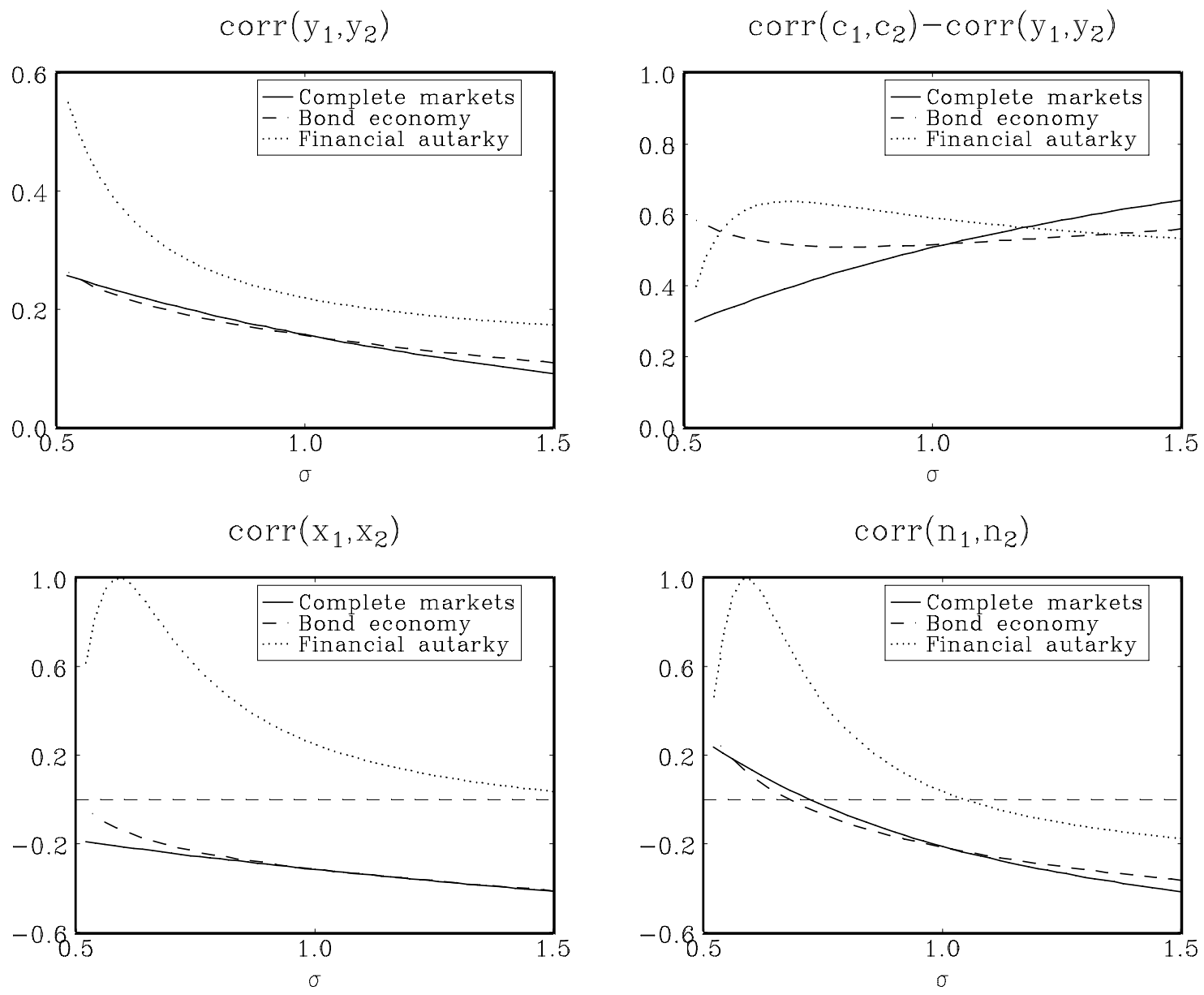

terms of trade $(p)$

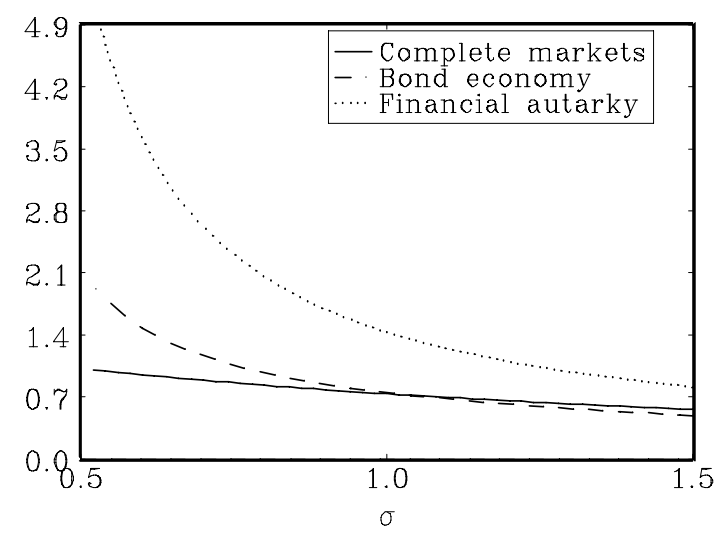

import ratio $\left(b_{1} / a_{1}\right)$

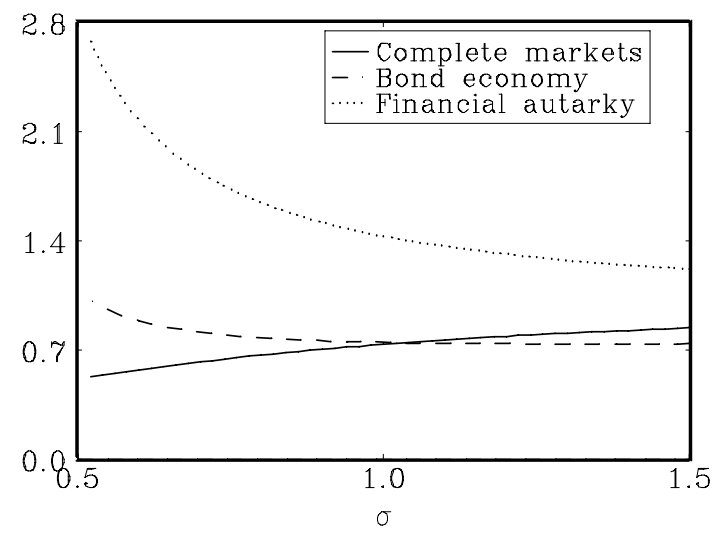


Figure 4: Varying $A_{1,2}$, the productivity spill-over term
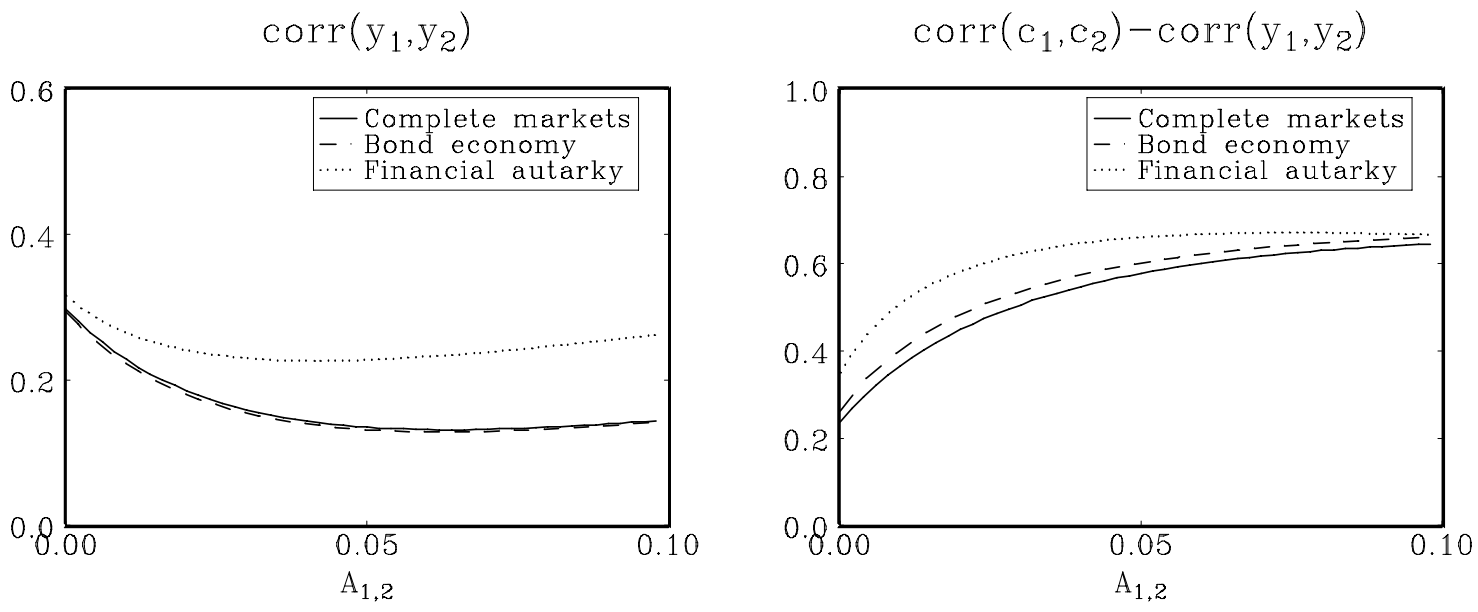

$$
\operatorname{corr}\left(\mathrm{x}_{1}, \mathrm{x}_{2}\right)
$$

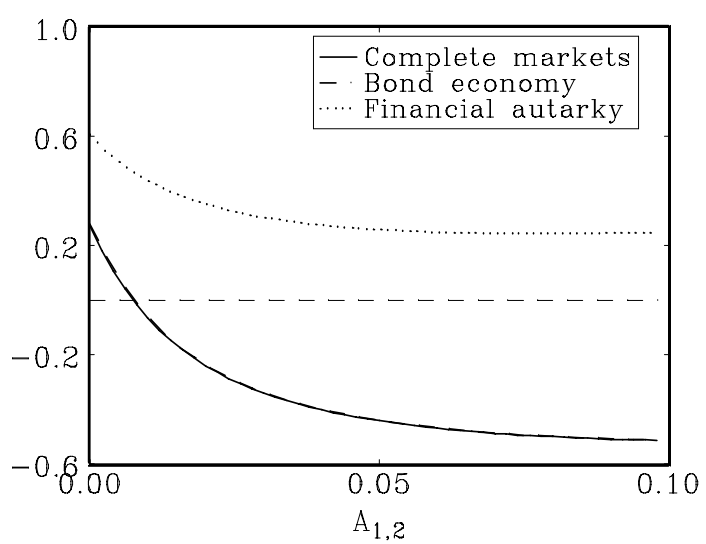

$\operatorname{corr}\left(\mathrm{n}_{1}, \mathrm{n}_{2}\right)$

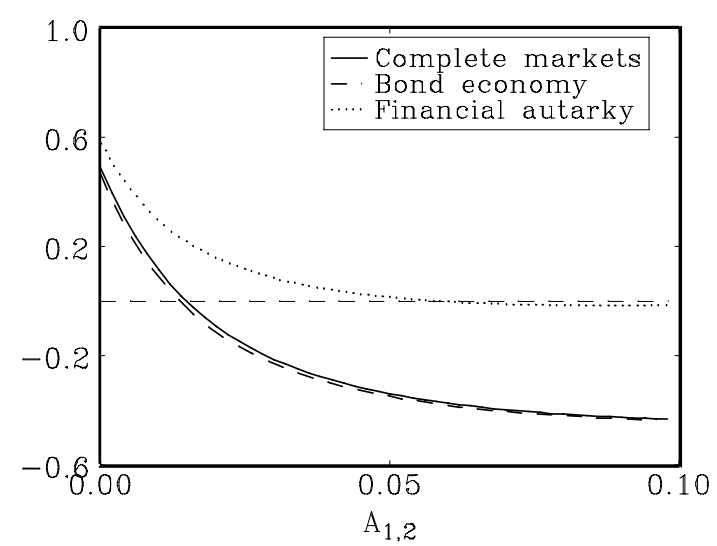

terms of trade $(p)$

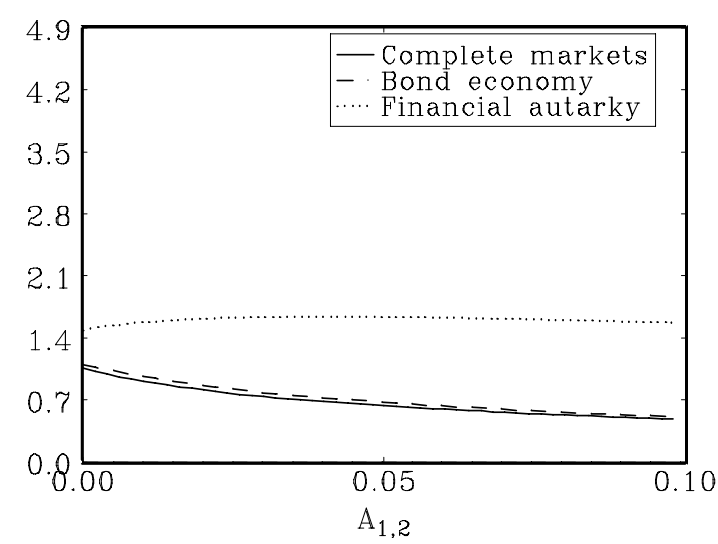

import ratio $\left(b_{1} / a_{1}\right)$

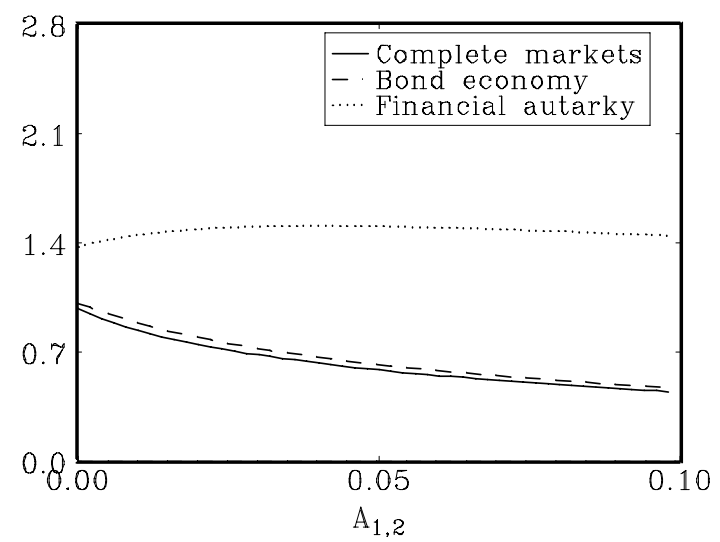

